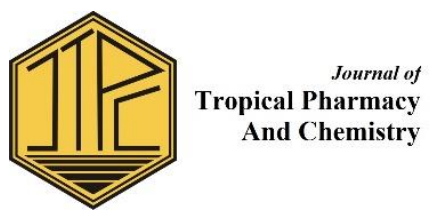

\title{
THE ANTIOXIDANT EFFECTIVITY OF COMBINATION BANANA PEEL EXTRACT AND ORANGE PEEL EXTRACT
}

\author{
Ramadhani Dwi Sula*, Ulil Fikri Nurhakimah, Elma Arifatul Sugito, \\ Ika Trisharyanti Dian Kusumowati
}

Faculty of Pharmacy University of Muhammadiyah Surakarta

*Email: k100150129@student.ums.ac.id

\begin{abstract}
Oxidation reactions to foods and drugs can be inhibited by using antioxidants that binding to free radicals and reactive molecules. The Ambonese banana (Musa paradisiaca) peel and orange (Citrus reticulata) peel have antioxidant activity potency. The aim of this research is knowing the antioxidant activity of combination Ambonese banana (Musa paradisiaca) peel and orange (Citrus reticulata) peel. IC50 for antioxidant activity potency between Ambonese banana (Musa paradisiaca) peel and orange (Citrus reticulata) peel is expected to increase the antioxidant activity if used a combination that can inhibit oxidation reaction. IC50 indicates the inhibit concentration of antioxidant activity. The compound that has the highest antioxidant activity will show lowest level of IC50. The antioxidant activity test was performed by DPPH method using UV-Vis spectrophotometer on $516 \mathrm{~nm}$ and color change of DPPH from purple to yellow when both of them react with an antioxidant compound. The results of IC50 of banana peel extract was $114 \mathrm{mcg} / \mathrm{mL}$; IC50 of orange peel extract was $22.2 \mathrm{mcg} / \mathrm{mL}$. The highest inhibition of the combination of both extracts was $73.53 \%$ consisting of $25 \mu \mathrm{L}(0,005 \%)$ sample of tangerine orange peel extract and $75 \mu \mathrm{L}(0,015 \%)$. The biggest inhibition of the combination of both extracts was $73.53 \%$ consisting of $25 \mu \mathrm{L}(0.005 \%)$ samples of tangerine orange peel extract and $75 \mu \mathrm{L}$ $(0.015 \%)$.
\end{abstract}

Keywords: Ambon banana peel, orange peel, antioxidant, DPPH, $\mathrm{IC}_{50}$

Submitted on: 10 July 2018

Accepted on: 31 July 2018

DOI: https://doi.org/10.25026/jtpc.v4i3.178

\section{INTRODUCTION}

The content of vitamins and minerals contained in the diet is responsible for the health of the body. The process of storing food also affects the quality of the food itself. This decrease in quality is due to oxidation that causes a change in the taste of each food. This can be prevented by the addition of antioxidants. Antioxidants are compounds that can inhibit oxidation reactions, by binding to free radicals and highly 
reactive molecules. Antioxidants that can not offset the increased amount of free radicals, antioxidants from outside the body.

Orange is a tropical or subtropical fruit that is widespread throughout the world as one of the most widely consumed fruits. Orange peels have the potential of antioxidant activity. According to research Tumbas et al., (2010), orange peel (Citrus reticulata) has antioxidant activity with $\mathrm{IC}_{50} \quad 0,179$ $\mathrm{mg} / \mathrm{mL}$ [1]. Based on the research of Ghasemi et al. (2009) showed that the total phenolic content in various citrus species was $66,5 \mathrm{mg}-396,8 \mathrm{mg} / \mathrm{mL}$ extract and flavonoid content ranged from 0.3 mg-31,1 mg GAE/g extract with $\mathrm{AlCl}_{3}$ colorimetric method [2]. The Boughendjioua and Boughendjioua study (2017) concluded that the essential oil component of Citrus reticulata was responsible for the antioxidant activity tested by the DPPH method [3].

Banana can be used in diarrhea, dysentery, canker sores, nephritis, gout, hypertension, heart disease. Bananas contain flavonoid compounds and other phytochemical compounds so they have potential antioxidant activity (Imam et al., 2011) [4]. Research Atun et al., (2007) showed the results that banana peel methanol extract contains compounds that have antioxidant activity [5].

Banana peel contains a variety of substances, including vitamin $\mathrm{A}$ and carotenoid substances that function as antioxidants. Banana peel (Moses parasidiacasapientum $L$ ) contains a total carotenoid of $6.203 \pm 0.004 \mu \mathrm{g} / \mathrm{g}$ and a carotenoid conversion of vitamin $\mathrm{A}$ of $124.06 \pm 0.08 \mathrm{IU}$. The $\mathrm{IC}_{50}$ value of banana extract of yellow amber banana is $2350,3 \mathrm{ppm}$ higher than $\beta$-carotene marker which has IC value of $565,76 \mathrm{ppm}$. (Suparmi and Prasetya, 2012) [6]. Alamsyah et al. (2016) studying antioxidant activity of banana extract combination with watermelon skin extract on lotion formulation showed that the combination of extract had better antioxidant activity [7].

Based on the above review, research is needed to investigate the antioxidant activity of banana peel extract and orange peel extract which is expected to have higher antioxidant activity.

\section{MATERIAL AND METHOD}

Banana and orange peels from Central Java - Indonesia, ethanol 96\% (E. Merck), ethanol absolute for analysis (Emsure), 2,2-diphenyl-1-picrylhydrazyl (DPPH) (Sigma-Aldrich), glassware (Pyrex), aquadest, rotary evaporator (Heidolph), spectrophotometer UV-Vis (UV SHIMADZU), glass ware (Pyrex), sonicator (Branson 1210), and micropipette (Soccorex).

\section{Extract Preparation}

\section{Preparation}

Banana and orange peels was dried for 3 days. It was grinded before extraction.

\section{Extraction}

Banana and orange peels was macerated using ethanol $96 \%$ (1:10) for 3 days at dark room and filtered. The filtrate was concentrated by rotary evaporator for 30 minutes. Extract was placed on watherbath to make a condensed extract.

\section{Preparation Standart Solution of Vitamin E}

Stock solution of vitamin $\mathrm{E}$ was taken $6.25,12.5,25,50$, and $100 \mu \mathrm{g} / \mathrm{mL}$ and added ethanol absolute up to the mark $(5,0 \mathrm{~mL})$. 


\section{Antioxidant activity test by DPPH method}

The release of the stable DPPH radical was used to test antioxidant activity from the combination of banana and orange peel extract. DPPH maximum absorption at $\lambda 516,4 \mathrm{~nm}$. The mixture reaction $(5 \mathrm{ml})$ contains total volume combination of banana and orange peel extract was $100 \mu \mathrm{L}, 1 \mathrm{~mL}$ of $0,4 \mathrm{Mm}$ DPPH $(15,7 \mathrm{mg}$ DPPH in $100 \mathrm{~mL}$ of ethanol absolute) and added ethanol absolute up to mark and made various concentrations of test solution dissolved in ethanol absolute. The solution was incubated for 30 minutes in the dark room and absorbance was measured at $\lambda 516,4$ $\mathrm{nm}$ using UV-Vis spectrophotometer. Lower absorbance indicated high restriction of free radical scavanging (\% inhibition)..

The $\mathrm{IC}_{50}$ value was determined by linear regression between concentration and percent inhibition of each sample. Preparation solution of series concentration of banana and orange extract $250 \mu \mathrm{g} / \mathrm{mL} ; 125 \mu \mathrm{g} / \mathrm{mL} ; 60$ $\mu \mathrm{g} / \mathrm{mL} ; 30 \mu \mathrm{g} / \mathrm{mL}$; and $15 \mu \mathrm{g} / \mathrm{mL}$.

\section{RESULT AND DISCUSSION}

Antioxidant assay of banana peel extract and orange peel extract is done with the initial step of extraction with the aim to draw the active antioxidant compound contained in the test material. In banana peel contains carotenoid compounds, phenolic compounds, and amine compounds (Pereira and Marashin, 2014) [8]. Revealed by (Milind and Dev 2012), that the orange peel contains phenolic compounds of flavone glycosides, neohesperidine, naringin, hesperidin, and narirutin, triterpenes; limonene and sitrol, polymetoxy flavones; tangeretin and nobiletin, as well as flavonoids; sitacidone, cytbration, and noradrenaline [9].
The extraction process was performed by a ratio of 1:10 (40 grams of banana peel which was soaked in $400 \mathrm{~mL}$ of $96 \%$ ethanol and 45 grams of tangerine peel immersed in $450 \mathrm{~mL}$ ethanol $96 \%$ ). From this comparison, it is expected that the amount of solvent which is 10 times more than the extract can attract a substantial active substance component. Ethanol is chosen because it is polar, nontoxic, cheap, and easy to obtain. The calculation percentage of yield extract contained in table 1 .

\section{Antioxidant Activity Test of Banana Peel Extract and Orange Peel Extract}

The method used in antioxidant testing is the DPPH method (2,2-diphenyl1-picrylhydrazyl). This test requires DPPH as a test reagent against samples suspected of containing active antioxidant compounds. This method is often used because the test is a simple, fast, and does not require many reagents such as other tests (xanthine oxidase, Thiocyanate method, total antioxidant) (Mailandari, 2012) [10].

The Extracts of banana peel and orange peel are taken with different volume of each stock solution with the concentration of each stock solution is $1 \%$. The antioxidant activity test on a banana extract of Ambon banana extract and orange peel extract using DPPH method to obtain \% inhibition and $\mathrm{IC}_{50}$ value. The value of $\mathrm{IC}_{50}$ is defined as the concentration of test compounds that can absorb free radicals by $50 \%$. The smaller the value of $\mathrm{IC}_{50}$ free radical damping activity is higher. The working principle of this measurement is the presence of stable free radicals, ie DPPH is mixed with antioxidant compounds that can donate hydrogen so that free radicals can be muted. In the following graph is the result of measurement of antioxidant 
activity combination of banana peel extract and orange peel extract.

$\mathrm{IC}_{50}$ values obtained from the calculation of linear regression equation in Figure 1 and 2, where the regression equation of banana skin extract is $\mathrm{y}=$ $2161,37 x+25,269$ and tangerine orange peel extract is $\mathrm{y}=1150,03 \mathrm{x}+24,4156$. The coefficient $y$ in each of the equations which have been called is $\mathrm{IC}_{50}$ whereas $\mathrm{x}$ obtained is the amount of concentration needed to be able to dampen $50 \%$ activity of radical of DPPH.

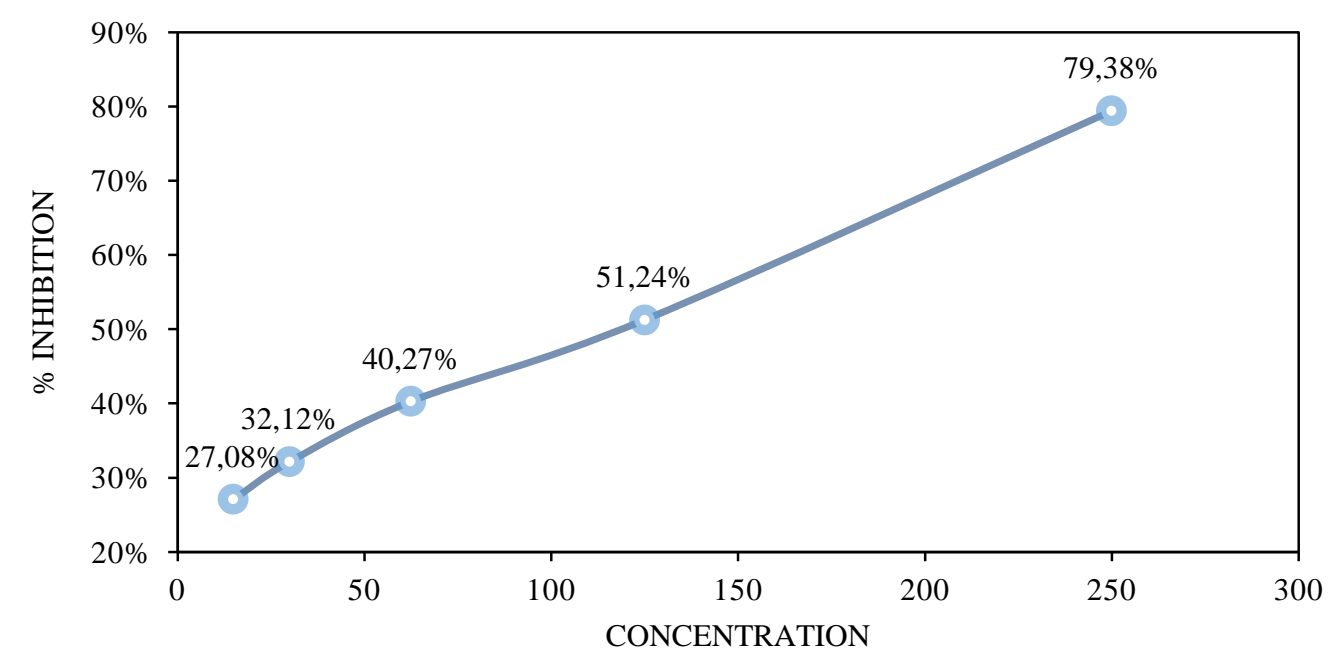

Figure $1 . \mathrm{IC}_{50}$ of Banana Peel Extract

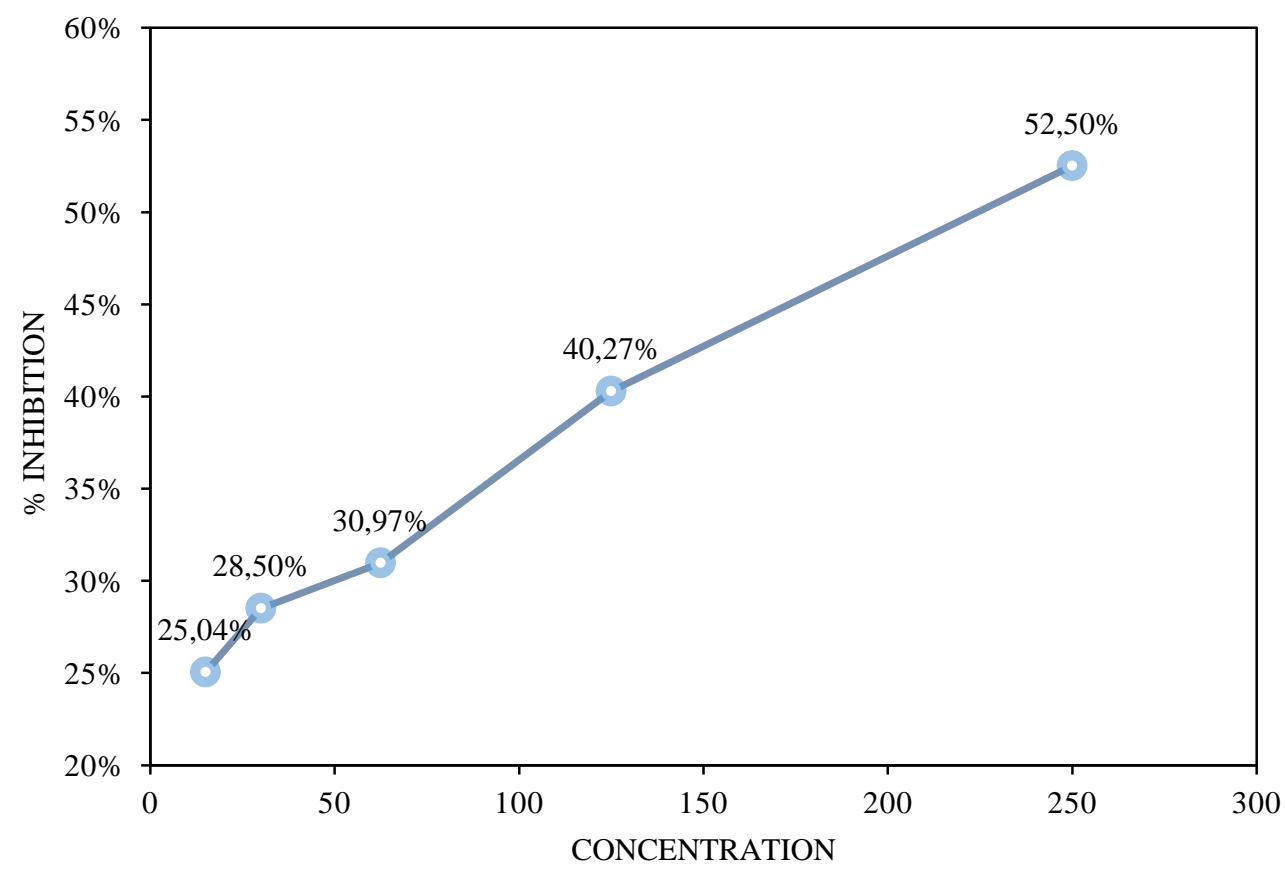

Figure 2. $\mathrm{IC}_{50}$ of Orange Peel Extract 
Table 3. \% Inhibition of Combination Banana Peel Extract and Orange Peel Extract

\begin{tabular}{cccccc}
\hline $\begin{array}{c}\text { Volume of } \\
\text { OrangePeel } \\
\text { Extract } \\
(1 \%)\end{array}$ & $\begin{array}{c}\text { Volume of } \\
\text { OrangePeel } \\
\text { Extract } \\
(1 \%)\end{array}$ & $\begin{array}{c}\text { Sample } \\
\text { Absorbance }\end{array}$ & $\begin{array}{c}\text { Percent } \\
\text { of } \\
\text { Inhibition }\end{array}$ & $\begin{array}{c}\text { Mean } \\
\text { Percent } \\
\text { of } \\
\text { Inhibition }\end{array}$ & $\begin{array}{c}\text { Deviation } \\
\text { Standard }\end{array}$ \\
\hline $100 \mu \mathrm{L}$ & $0 \mu \mathrm{L}$ & 0,931 & $63,71 \%$ & $64,58 \%$ & \\
$(0,02 \%)$ & $0 \%$ & 0,638 & $64,58 \%$ & & 0,870 \\
& & 0,590 & $65,44 \%$ & & \\
$50 \mu \mathrm{L}$ & $50 \mu \mathrm{L}$ & 0,541 & $81,67 \%$ & $83,11 \%$ & \multirow{2}{*}{$(0,281$} \\
$(0,01 \%)$ & $(0,01 \%)$ & 0,319 & $83,52 \%$ & & \\
& & 0,451 & $84,13 \%$ & & 0,862 \\
$75 \mu \mathrm{L}$ & $25 \mu \mathrm{L}$ & 0,631 & $79,83 \%$ & $80,73 \%$ & \\
$(0,015 \%)$ & $(0,005 \%)$ & 0,301 & $80,81 \%$ & & 1,419 \\
& & 0,243 & $81,55 \%$ & & \\
$25 \mu \mathrm{L}$ & $75 \mu \mathrm{L}$ & 0,253 & $84,87 \%$ & $88,68 \%$ & \\
$(0,005 \%)$ & $(0,015 \%)$ & 0,337 & $86,47 \%$ & & \\
& & 0,303 & $87,70 \%$ & & \\
$0 \mu \mathrm{L}$ & $100 \mu \mathrm{L}$ & 0,237 & $90,28 \%$ & $90,37 \%$ & \\
$0 \%$ & $(0,02 \%)$ & 0,349 & $90,41 \%$ & & \\
& & 0,204 & $90,41 \%$ & & \\
\hline
\end{tabular}

From the results above can be seen that the more volume of banana peel extract added to the higher the value of inhibition will be generated. This is supported by the $\mathrm{IC}_{50}$ value of each banana peel extract and orange peel extract.

The combination of the two extracts showed the highest \% inhibition was the fourth series with $25 \mu \mathrm{L}(0.005 \%)$ sampling of orange peel extract and $75 \mu \mathrm{L}$ $(0.015 \%)$ of banana peel extract. The positive control used in this study is vitamin $\mathrm{E}$. The use of positive controls on antioxidant activity testing is to find out how strong the antioxidant potential is in banana peel extract and orange peel extract.

If the $\mathrm{IC}_{50}$ value of the sample approaches the positive $\mathrm{IC}_{50}$ control value then it is said that the sample has potential as one of the most powerful antioxidant alternatives. The results of vitamin $\mathrm{E}$ test showed $\mathrm{IC}_{50}$ value $12.59 \mu \mathrm{g} / \mathrm{mL}$ [11]. From $\mathrm{IC}_{50}$ result obtained from positive control can be seen that bark extract of banana and orange have $\mathrm{IC}_{50}$ value bigger than positive control which means capture ability of free radical of vitamin $\mathrm{E}$ is better when compared with banana peel extract of ambon and orange peel extract.

\section{CONCLUSION}

Based on the results of testing the antioxidant power of banana extract of ambon and orange peel extract can be summarized, $\mathrm{IC}_{50}$ value of each banana leaf extract and tangerine skin extract is $114 \mu \mathrm{g} / \mathrm{mL}$ and $222 \mu \mathrm{g} / \mathrm{mL}$. The combination of the two extracts has shown higher levels of antioxidants than the antioxidant levels of tangerine orange skin extract but has not shown maximum results when compared with antioxidant levels of banana peel extract alone. 


\section{ACKNOWLEDGMENT}

We thank to all laboratory assistans in Faculty of Pharmacy Muhammadiyah University of Surakakarta for the technical assistant.

\section{REFERENCES}

[1] Tumbas, V.T., Ćetković, G.S., Djilas, S.M., Čanadanović-Brunet, J.M., Vulić, J.J., Knéz, Ž. and Škerget, M., 2010, Antioxidant Activity of Mandarin (Citrus reticulata) Peel, Acta Periodica Technologica, 41, 195-203.

[2] Ghasemi, K., Ghasemi, Y. and Ebrahimzadeh, M.A., 2009, Antioxidant Activity, Phenol and Flavonoid Contents of 13 Citrus Species Peels and Tissues, Pakistan Journal of Pharmaceutical Sciences, 22 (3), 277-281.

[3] Boughendjioua, H. and Boughendjioua, Z., 2017, Chemical Composition and Biological Activity of Essential Oil of Mandarin (Citrus reticulata) Cultivated in Algeria., International Journal of Pharmaceutical Sciences Review and Research, 44 (40), 179-184.

[4] Imam, M.Z., Akter, S., Mazumder, M.E.H. and Rana, M.S., 2011, Antioxidant Activities of Different Parts of Musa sapientum L. ssp. Sylvestris Fruit, Journal of Applied Pharmaceutical Science, 1 (10), 6872.

[5] Atun, S., Arianingrum, R., Handayani, S., Rudyansyah and Garson, M., 2007, Identification and Antioxidant Activity Test of Some Compounds from Methanol Extract
Peel of Banana (Musa paradisiaca Linn.), , 7 (1), 83-87.

[6] Suparmi and Prasetya, H., 2012, Aktifitas Antioksidan Ekstrak Kasar Pigmen Karotenoid pada Kulit Pisang Ambon Kuning (Musa parasidiaca sapientum): Potensi sebagai Suplemen Vitamin A, , 4 (1), $78-8$

[7] Alamsyah, N., Djamil, R. and Rahmat, D., 2016, Antioxidant Activity of Combination Banana Peel (Musa paradisiaca) and Watermelon Rind (Citrullus vulgaris) Extract in Lotion Dosage Form, , 9

[8] Pereira, A. dan Maraschin, M., 2014, Banana (Musa spp) from Peel to Pulp: Ethnopharmacology, Source of Bioactive Compounds and its Relevance for Human Health, Journal of Ethnopharmacology, 160 (2015): 149-163.

[9] Milind, P. \& Dev, C., 2012, Orange of Benefits, International Research Journal Pharmachy, 3(7), 59-64.

[10] Mailandari, M., 2012, Uji aktivitas antioksidan ekstrak daun garcinia kydia roxb dengan metode DPPH dan identifikasi senyawa kimia fraksi ekstrak yang aktif. Skripsi, Universitas Indonesia, Depok.

[11] Kusumowati, I. T. D., Sudjono, T. A., Suhendi, A., Da'i, M., Wirawati, R., 2012, Correlation Phenolic Content and Antiradical Activities Ethanol Ekstract Leaves Four Plant Drug Indonesia (Piper bettle, Sauropus androgynous, Averrhoa bilimbi, dan Guazuma ulmifolia), Pharmacon, 13 (1), 1-5.

How to cited this article :

Sula, R.D., Nurhakimah, U.F., Sugito, E.A., Kusumowati, I.T.D., 2018. The Antioxidant Effectivity of Combination Banana Peel Extract and Orange Peel Extract. J. Trop.Pharm. Chem. 4(3); 136-141. 